\title{
CORRESPONDENCE.
}

November 29, 1915.

To the Editor of The Journal of Laryngology, Rhinology, and Otologr.

Dear Srr,--After Dr. J. S. Fraser's paper ${ }^{1}$ had been read at the discussion on mastoid grafting at the meeting of the Otological Section, I stated that for many vears past, in the case of my patients, a slice of skin had been removed from the upper border of the skin flap above the ear to prevent the ear dropping.

In confirmation of this, I am writing to mention that on page 551 of the second edition of $\mathrm{my}$ kook, published in 1901, the following passage occurs :

"Unless special precautions are taken, the auricle will slip to a much lower level than its normal position. In order to prevent this, it is well to remove a slice from the upper border of the flap, and then pass some sutures through the flap, and fasten them over drainage-tubing to the skin above the line of the incision."

Yours sincerely,

T. Mak K Howell.

\section{NEW INSTRUMENT.}

The possible advantages of a malleable over a rigid metal curette in the performance of intra-nasal operations was brought to my mind by the difficulty I often experienced in using the rigid instrument in the more or less inaccessible regions of the nasal cavity and its adnexes. I have accordingly had an instrument made for me by Messrs. Mayer and Meltzer which has a malleable metal shaft four inches in length,

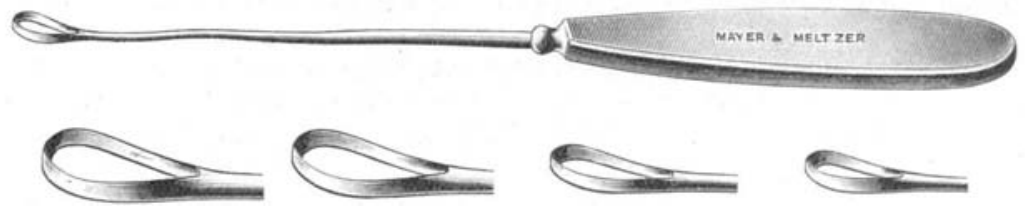

and permits of the curette being turned in any lateral or anteroposterior direction as desired. This instrument, the curette of which is made in four sizes, I have found of great utility in the performance of all intra-nasal sinus operations, and is of special use in the removal of adenoid remains in and about Rosenmüller's fossa by the transnasal route.

Care must be taken to avoid bending the instrument at that place where the rigid curette is joined to the malleable copper shaft.

J. B. Horgan, M.B.

\section{NOTES AND QUERIES.}

We understand that a second edition of Sir StClair Thomson's "Diseases of the Nose and Throat" is in the press. It is headed with the Excelsior motto from Michelet: "Un livre est toujours un moyen de faire un meilleur tivre."

\footnotetext{
1 See p. 80.
} 


\section{NOW READY.}

33rd Year. About 1,000 pages. 10/- net. Enriched with many Illustrations in the Text, and $7 \mathrm{I}$ Plates in Colour and Black and White.

A new and very legible type is used in the production of this issue, and in every respect its contents fully maintain the high

reputation won by its predecessors.

\section{THE}

\section{MEDICAL AN ANNUAL, 1915.}

\section{A YEAR BOOK OF TREATMENT, AND PRACTITIONER'S INDEX.}

A DICTIONARY OF MODERN THERAPEUTICS, A DICTIONARY OF NEW TREATMENT, with a Special Section for NAVAL \& MILITARY SURGERY.

\section{Contributors :}

E. WYLLYS ANDREWS, A.M., M.D., Chicago. Sir CIYAS. BENT BALL, Bart, M.D., F.R.C.S. JOSEPH G. BLUMFELD, B.A., M. D. FRANCIS D. BOYD, C.M.G., M.D, F.R.C.P. FRANCIS J. CHARTERIS, M.D., B.CH. G. LENTHAI, CHEATLE, c.r.o., C, B, F.r.c.s. JOHN D. COMIRIE, M.A., M.D.

CAREY F. COOMPS, M. v., M.R.C.P.

JOHN S. FRASER, M.B., CH.R., F.R.C.S. HERBERT FRENCH, M.A., M.D., F.R.C.P. BRIDEN GLENDINING, M.S., M.B. F.R.C.S. EDWARD W. GOODALL, M.D., B.S. FRANCIS W. GOYDER, B.A., N.r., F.R.C.S. ERNEST W. HEY GROVES, M.D., M.S., F,R*C. s. OSKAR C. GRUNER, M.D. Lond.

C. THURSTAN HOLLAND, M.R.C.S., L.R.C.r. ROBERT HUTCHISON, M.D., F.R.C.Y.
COL. LOUIS A. LA G.ARDE, U.S.A. Army Medical Corps (Retired).

FREDERICK LANGMEAD, M.D., F.R.C.P.

E. G. GRAHAM LITTLE, M.D., F.R.C.P.

CHARLES FRED. MARSHALL, M.D., F.R.C.S.

KEITH W. MONSARRAT, N.B., F.R.C.S.

JOS. J. PERKINS, M.A., M.B., F.R.C.l'.

BEDFORD PIERCE, M.D., F.R.C.P.

JOSEPH PRIESTLEY, B.A., M.D., D.P.H.

StR LEONARD ROGERS, Lt..Col. I.M.s., M.D., F.R.C.S., Calcutta.

A. RENDLE SHORT, N.D., B.S., F.R.C.S.

PURVES STEWART, M.A., M.D., F.R.C.P.

A. HUGH THOMPSON, M.A., M.D.

J. W. THOMSON WALKER, F.R.C.S.

A. GASCOIGNE WILDEY, Dep. Surg.-Gen., R.N. JOHN H. YEARSLEY, F.R.c.s.

Lancet.-"We have nothing but praise for this Annual."

BRISTOL, ENG.: JOHN WRIGHT \& SONS LTD. LONDON : SIMPKIN, MARSHALL, HAMILTON, KENT \& CO. LTD. 


\section{MAYER \& MELTZER,}

Surgical Instrument Makers.
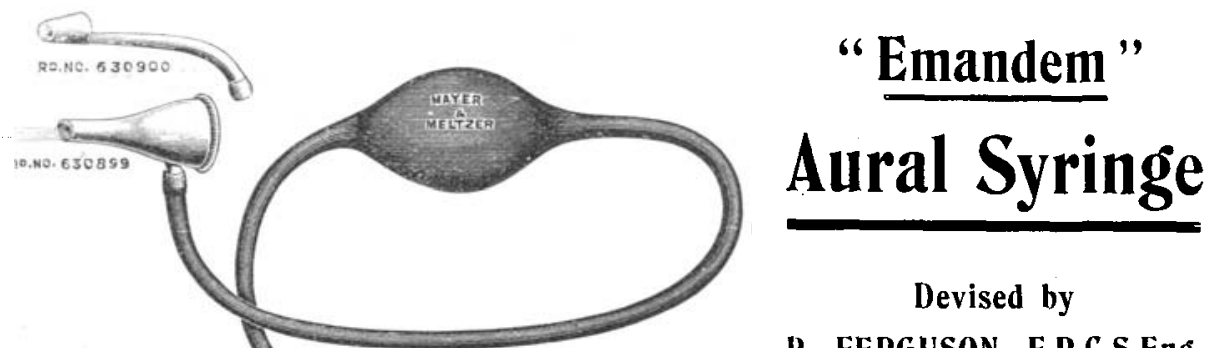

Devised by

P. FERGUSON, F.R.C.S.Eng.

The efferent tube fitted into a speculum gives a flat stream of water.

The outflow from the speculum being greater than the ingoing stream, considerable force may be used without danger.

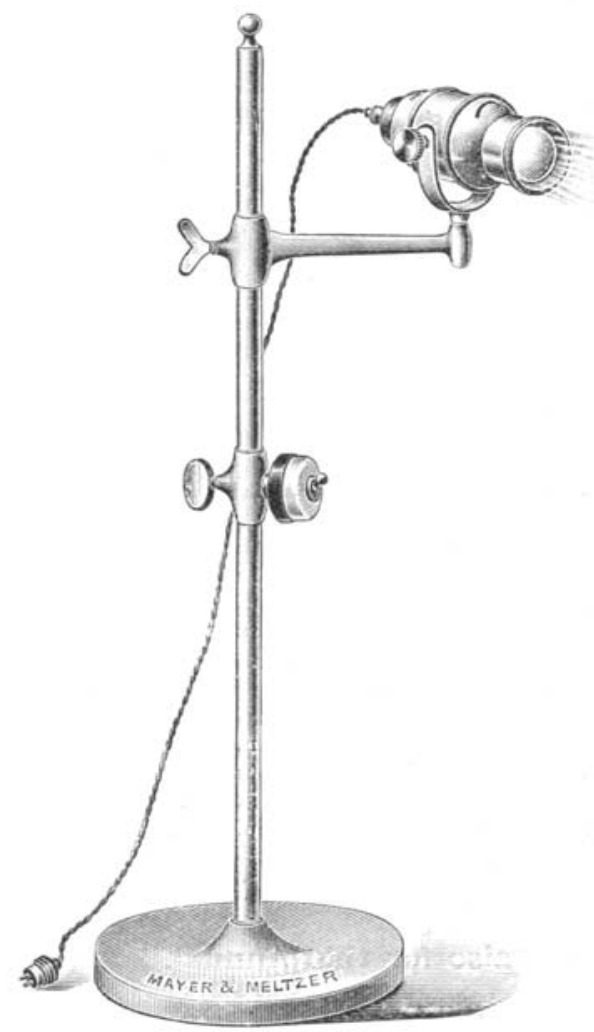

The operator has the meatus under inspection while syringing, and can mancuvre to remove any foreign body.

The smaller nozzle shown in engraving forms a safe syringe to entrust to a patient for self-use.

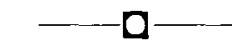

\section{"Emandem"}

\section{Improved Metallic}

\section{Filament Lamp.}

(Registered Design.)

Gives a light of intense brilliancy (40-5o c.p.), almost equal to the Nernst Lamp, which is now unobtainable. Full particulars on application.

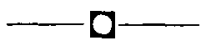

MAYER \& MELTZER, 71, GT. PORTLAND STREET, LONDON.

And at MELBOURNE, CAPETOWN, JOHANNESBURG. 


\section{MAYER \& MELTZER,}

Surgical Instrument Makers.

ESTABLISHED OVER FIFTY YEARS.

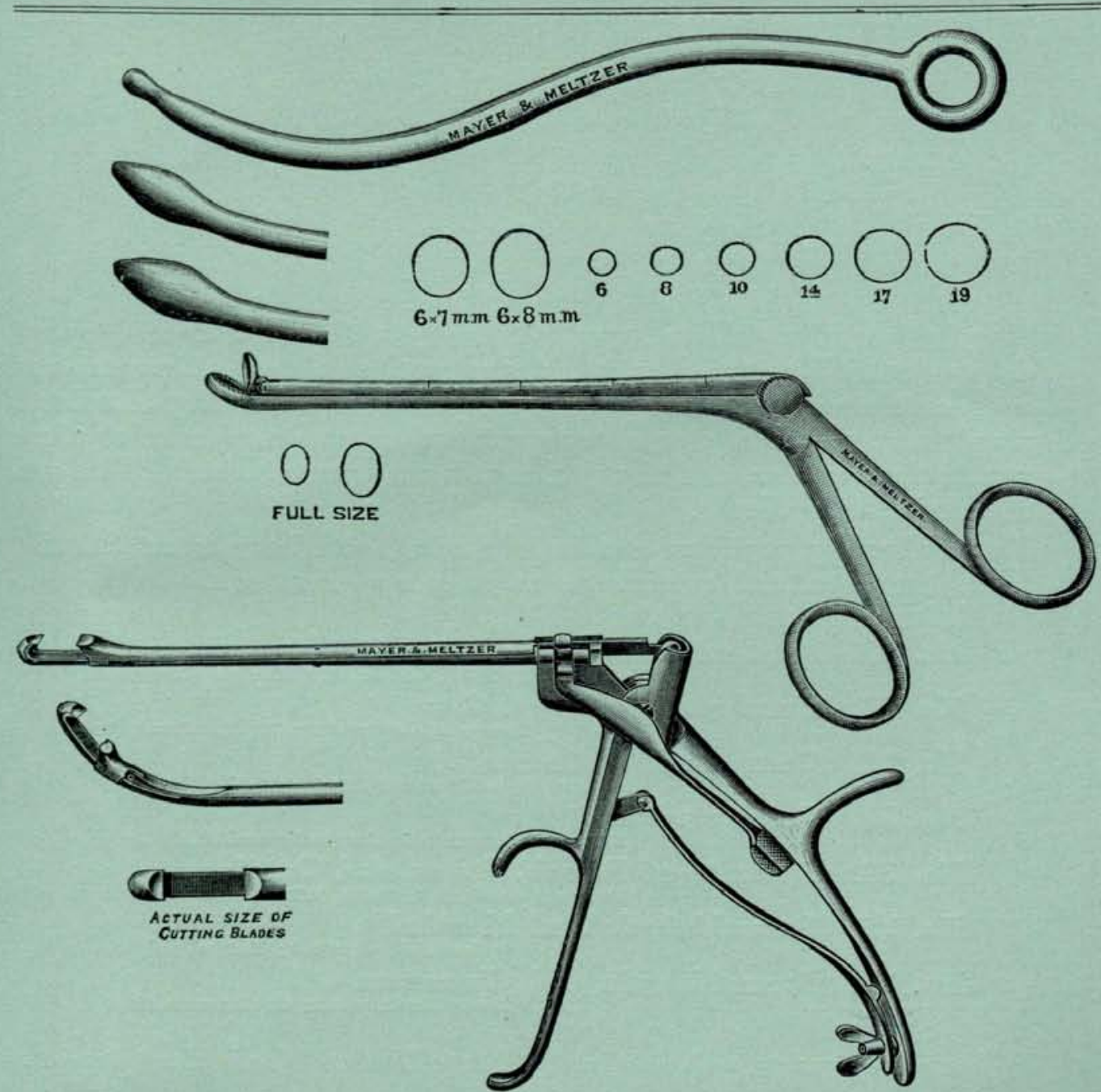

Instruments as used by Dr. Watson-Williams for the Intra-Nasal Operation for Frontal Sinus Suppuration. Full Particulars on application.

MAYER \& MELTZER, 71, GREAT PORTLAND ST., LONDON. Branches: MELBOURNE; CAPE TOWN; JOHANNESBURG. 


\section{The "Allenburys" (") (мвтгатво) Throat Pastilles}

Efficient

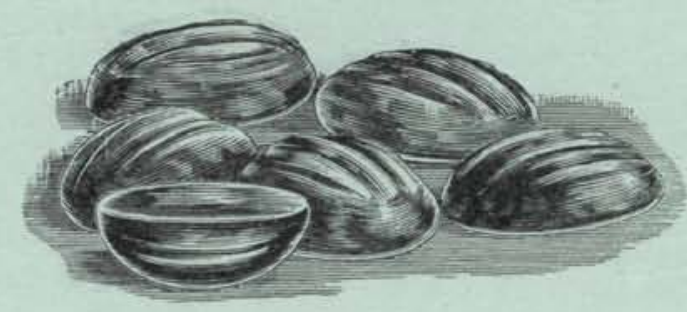

Palatable

The basis of the "Allenburys" Throat Pastilles is a special pate de jujube. The pastilles are demulcent, soluble and palatable, and contain accurate amounts of pure active drugs. They dissolve slowly and uniformly, so ensuring the thorough suffusion of the mucous membrane, and the prolonged continuous direct effect of the active ingredients.

The following pastilles are largely used, and have been found from long practical experience to be very efficacious.

No. 9. Menthol, Cocaine and Red Gum

No. 23. Eucalyptus and Red Gum

No. 28. Compound Guaiacum

No. 29. Compound Rhatany

Guaiacum, Br. 1; Chlorate of Potash, gr. 2; Red Gum, gr. $\frac{\text { a }}{3}$

No. 29. Compound Rhatact of Rhatany, gr. 2; Cocaine Hydrochlor, gr. 1/20th

No. 38. Chlorate of Potash, Borax and Cocaine

No. 75. Formaldehyde and Menthol

No. 77. Formaldehyde and Cinnamon Oil

Formaldehyde, min. 1: O1. Cinnamon, min. $\frac{1}{2}$

1/- box of any variety, with detailed list, free to Medical Men in Great Britain.

IMPORTANT.-To ensure the supply of these active and reliable medicinal products, medical men should designate the

"ALLENBURYS" Pastilles in their prescriptions.

Allen \& Hanburys Itd. London 